\title{
Use of dewatered alum sludge as a substrate in reed bed treatment systems for wastewater treatment
}

\author{
Y. Q. ZHAO ${ }^{1} *$, A. O. BABATUNDE ${ }^{1}$, M. RAZALI ${ }^{1}$ and F. HARTY ${ }^{2}$ \\ ${ }^{1}$ Centre for Water Resources Research, School of Architecture, Landscape and Civil \\ Engineering, University College Dublin, Belfield, Dublin 4, Ireland \\ ${ }^{2}$ FH Wetland Systems Ltd., Gaggin, Bandon, Co. Cork, Ireland
}

\section{ABSTRACT}

In this paper, two laboratory scale simulated reed beds were investigated for the purpose of assessing the feasibility and effectiveness of using dewatered alum sludge as a possible substrate for wastewater treatment reed bed systems. One horizontal subsurface flow set-up and one vertical flow set-up were used. The horizontal flow system was planted with Phragmites australis while the vertical flow system was left unplanted. Thus, the latter was more akin to a sand filter system, but was examined with the

* Address correspondence to Y.Q. Zhao, Centre for Water Resources Research, School of Architecture, Landscape and Civil Engineering, Philips Building, University College Dublin, Belfield, Dublin 4, Ireland; Phone: +353-1-7163215, Fax: +353-1-7167399; E-mail: yaqian.zhao@ucd.ie 
potential use as a planted vertical reed bed system. The influent source used was farmyard wastewater. It is expected that the present study will provide the basis for long-term and large-scale trials in realising the concept of integrating "waste" into treatment processes. Results obtained so far have shown that the dewatered alum sludge holds great promise as a low-cost resource media for use in reed bed treatment systems. Appreciable and stable performance was obtained during the continuous operation at high hydraulic, organic and phosphorus loadings. In particular, both wetlands achieved over $90 \%$ phosphorus removal, reflecting the significant advantage of this novel approach over conventional reed bed treatment systems. However, extensive research into possible surface clogging and possible release of some substances from the sludge to the treated effluent is necessary to ensure reliability of the system. This will help make the alum sludge based reed bed environmentally and economically justifiable.

Key Words: Alum sludge; Constructed wetland; Reed bed; Reuse; Substrate; Wastewater treatment

\section{INTRODUCTION}

In recent times, the treatment and disposal of water treatment plant derived sludges (e.g. alum sludge when aluminium sulphate was used as coagulant) has become a major challenge to the water industry, prompting widespread research and development into 
its possible reuse. To date, most of the research efforts have been done to assess the feasibility of reusing the sludges in the construction and manufacturing industries. ${ }^{[1]}$ Their only application in the wastewater treatment process to date has been codischarging such sludges with sewage sludge, to enhance sewage sludge stability. Sludge reuse in wastewater treatment is clearly an option open to prospective research and in particular, the use of such sludge as a media in reed bed treatment systems.

The media in reed bed treatment systems plays an integral role in various physical, chemical and biological processes that remove pollutants in wastewater. Traditionally, different combinations of soil, sand and gravel have been used as media in the reed bed. ${ }^{[2]}$ Numerous studies have shown that the reed beds based on these conventional media are capable of meeting the required $\mathrm{BOD}_{5}$ and $\mathrm{COD}$ reductions. However, it is often difficult to achieve substantial removal of certain inorganic nutrients, e.g. orthophosphate and ammoniacal-nitrogen, in reed beds with the conventional media at the design sizes selected for $\mathrm{BOD}_{5}$ and SS removal. Therefore, one of the current research objectives in subsurface flow reed bed technology is to discover new materials as alternative reed bed substrate, that will increase the effectiveness and, hopefully, reduce the capital cost. It has been reported that natural and artificial materials including lightweight aggregates, ${ }^{[3]}$ shale, ${ }^{[4]}$ apatite, ${ }^{[5]}$ dolomite, ${ }^{[6]}$ ochre, ${ }^{[7]}$ oyster shell ${ }^{[8]}$ and lime and iron drinking water treatment residuals ${ }^{[9]}$ have been investigated as seed or main substrate in reed beds for wastewater treatment. 
To explore the use of dewatered alum sludge as a reed bed substrate, two laboratory scale simulated reed beds were set up and used with real wastewater influent. The rationale for using alum sludge is as follows: (1) Alum sludge is a by-product of the drinking water treatment process, where aluminium sulphate is used as the primary coagulant. Generally, alum sludge is treated as a non-hazardous waste in the EU, but it must now be disposed appropriately since the introduction of the Irish Waste Management (Licensing) Regulations in 1997. (2) Its disposal and management has become a significant environmental issue, due to the large amount produced. Several million tons of water treatment sludge are produced in Europe every year. ${ }^{[10]}$ (3) Reuse of dewatered alum sludge is encouraged by the environmental policy of "reduce, reuse, recycle" for sustainable development. (4) Previous work done by the authors has demonstrated that the dewatered alum sludge has a considerable phosphorus $(\mathrm{P})$ adsorption capacity using different P-species ${ }^{[11-13]}$ and thus has the potential to be used as a valuable resource (adsorbent or filter medium) in wastewater treatment engineering. Therefore, this study aims to preliminarily assess the feasibility of using the dewatered alum sludge as a substrate material in reed bed treatment systems. The influent source chosen was a farmyard wastewater, considering its nature of $\mathrm{P}$ abundance.

\section{MATERIALS AND METHODS}

Dewatered alum sludge cakes (with moisture content of 72-75\%) were collected from a

Water Treatment Plant outside Dublin where aluminium sulphate is employed for 
flocculating reservoir water. Sludge cakes were ground and then sieved into various particle sizes. In this study, particles of $1.18-2.36 \mathrm{~mm}$ were used as the main substrate in the laboratory scale reed beds. Inductively coupled plasma-atomic emission spectrometry analysis of the alum sludge showed that $46 \%$ of $1 \mathrm{~g}$ of the dried sludge is made up of $\mathrm{Al}_{2} \mathrm{O}_{3} \cdot{ }^{[14]}$ The wastewater was obtained from the secondary holding tank of an animal farm with about 2000 livestock units including sheep, pigs, cattle and horses. The farmyard wastewater had an average initial concentration of $765 \mathrm{mg} / \mathrm{L}, 1150 \mathrm{mg} / \mathrm{L}$, $104 \mathrm{mg} / \mathrm{L}$ and $510 \mathrm{mg} / \mathrm{L}$ of $\mathrm{BOD}_{5}, \mathrm{COD}, \mathrm{PO}_{4}{ }^{3-}$ and $\mathrm{SS}$ respectively. The $\mathrm{pH}$ of the wastewater is in the range of 6.7-7.4. Two lab-scale simulated reed bed treatment systems were constructed in the laboratory: (1) A vertical flow un-vegetated set-up was constructed using a Pyrex column (internal diameter of $7.4 \mathrm{~cm}$ ), filled with the alum sludge to a depth of $30 \mathrm{~cm}$ on a $10 \mathrm{~cm}$ base of washed gravel. The percentage of pore volume was measured to be $50 \%$ of total sludge volume; (2) A lab-scale horizontal flow reed bed was constructed using Pyrex plates (plan surface $40 \mathrm{~cm} \times 10 \mathrm{~cm}$ ) and was filled with the alum sludge to a depth of $10 \mathrm{~cm}$. Nursery grown common reeds, Phragmites australis, were planted into the bed. The inlet and outlet sections of the reed bed were filled with gravel to ensure an evenly distributed flow. Figure 1 shows the layout of the two lab-scale beds.

[Fig. 1 here]

Trials of wastewater treatment efficiency in the two simulated reed beds were conducted separately. For the vertical-flow un-vegetated unit, trials were conducted by introducing 
pre-diluted wastewater using a peristaltic pump (Watson Marlow, UK) in a continuous mode with flow rate of $10 \mathrm{~L} / \mathrm{d}$. The bed was kept saturated at all times with the influent wastewater set at a predetermined level above the surface of the sludge. The system was subjected to a high hydraulic loading of $2.31 \mathrm{~m}^{3} / \mathrm{m}^{2}$.d for over 38 days. Trials in the horizontal-flow vegetated sludge bed were performed under an intermittent feeding operation, realised by timer controlled peristaltic pumps. The reed bed was operated for 193 days at a constant wastewater supply of $8 \mathrm{~L} / \mathrm{d}$ which corresponds to a hydraulic loading of $0.80 \mathrm{~m}^{3} / \mathrm{m}^{2}$.d. Samples of the influent and effluent for both wetlands were collected and analysed for $\mathrm{BOD}_{5}$ (Hach BODTrack Apparatus), $\mathrm{COD}, \mathrm{PO}_{4}{ }^{3-}$, $\mathrm{SS}$ (all using Hach DR/2400 spectrophotometer), $\mathrm{pH}$ (WTW, $\mathrm{pH}-325$ ), and periodically for effluent $\mathrm{Al}^{3+}$ (Hach DR /2400 spectrophotometer).

\section{RESULTS}

\section{Vertical flow un-vegetated sludge bed}

The performance of the vertical flow un-vegetated sludge bed is illustrated in Figure 2 and summarised in Table 1. Removal rates of 25\% COD, $50 \%$ SS and $99.5 \% \mathrm{P}$ were achieved. The significant removal of $\mathrm{P}$ suggests that both the soluble and particulate forms of $\mathrm{P}$ normally present in such wastewater were either filtered or adsorbed by the alum sludge bed. COD removal was quite low, suggesting that only particulate COD was removed via filtration and that the system is biologically inactive due to the relatively short operation time. The vertical flow bed also removed SS via filtration and 
this resulted in a gradual build up of solids on the surface. Data obtained showed that the $\mathrm{pH}$ of the effluent was somewhat lower than that of the influent, although the drop was insignificant. The release of $\mathrm{H}^{+}$ions into the effluent during the hydrolysis of the alum sludge could account for the drop in $\mathrm{pH} .{ }^{[14]}$

[Fig. 2 here]

[Table 1 here]

During the $25^{\text {th }}$ day of operation (see Fig. 2), the wetland was intentionally subjected to a shock load for 1 hour to test the response of the system. Less diluted farmyard wastewater with concentration of COD, P and SS of $347 \mathrm{mg} / \mathrm{L}, 45 \mathrm{mg}-\mathrm{PO}_{4}{ }^{3-} / \mathrm{L}$ and 189 $\mathrm{mg} / \mathrm{L}$, respectively, was introduced to the sludge bed. It can be seen from Figure 2 that the effects of this shock load on the system were minor and barely noticeable. Although the effluent SS and COD values increased immediately following the introduction of the shock load, they returned to normal levels after 8 hours. The system demonstrated a highly stable performance and in particular, $\mathrm{PO}_{4}{ }^{3-}$ levels in the effluent were consistently low (Fig. 2).

\section{Horizontal flow sludge based reed bed}

Figure 3 shows the fluctuations in both the influent and effluent for $\mathrm{BOD}_{5}, \mathrm{COD}, \mathrm{P}$ and SS levels over time during the horizontal flow reed bed trial. Results from the trials are 
summarised in Table 2. Significant removal of both $\mathrm{BOD}_{5}$ and COD was achieved in the system and over $90 \%$ of the influent $\mathrm{P}$ was consistently removed. The consistently high removal of influent $\mathrm{P}$ highlights the beneficial role of the dewatered alum sludge in the trial system. A higher pollutant removal efficiency was observed in the later stage (over 140 days) of the trial period. This coincided with higher pollutant loadings as shown in Figure 3. It may be attributed to the matured state of the reed bed in which chemical processes, microorganisms and the reeds interact for maximum system efficiency.

[Fig. 3 here]

[Table 2 here]

The sustained removal of $\mathrm{P}$ during the entire trial period of 193 days also reflects the strong P-immobilization ability of the alum sludge. This suggests justification for its integration into the reed bed treatment process. By taking into account the total $\mathrm{P}$ loaded and immobilized by the sludge, a calculated mass of $9.7 \mathrm{mg}-\mathrm{PO}_{4}{ }^{3-} / \mathrm{g}$ sludge was determined during the entire operation period. This contradicts the maximum adsorption capacity of $7.2 \mathrm{mg}-\mathrm{PO}_{4}{ }^{3-} / \mathrm{g}$ sludge derived from the batch tests using the Langmuir isotherm (data not shown). This suggests that the theoretical batch-test estimation of adsorption capacity may lead to a biased result when applied to a real treatment system like reed beds, as reported by Dong et al. ${ }^{[8]}$ and Arias and Brix. ${ }^{[15]}$ The reason may be attributed to the fact that the adsorption capacity from the batch test does not take into 
account other processes in reed bed treatment systems, such as plant uptake, sedimentation and biological processes. ${ }^{[6]}$

Monitoring of $\mathrm{Al}^{3+}$ in the effluent was done to ascertain any release of $\mathrm{Al}^{3+}$ during the flow of the wastewater through the system. This is considered very important since any release of $\mathrm{Al}^{3+}$ may pose potential environmental and health threats. Results obtained as shown in Figure 4 indicates that the $\mathrm{Al}^{3+}$ in the effluent ranged from 0.03 to $0.11 \mathrm{mg} / \mathrm{L}$. Compared with the aluminium in Irish drinking water standard of 0.05 to $0.20 \mathrm{mg} / \mathrm{L}$, $\mathrm{Al}^{3+}$ in effluent of the sludge bed is insignificant, suggesting no considerable release of $\mathrm{Al}^{3+}$ from the alum sludge. This may be ascribed to the strong chemical combination of alumnimun and phosphorus during the adsorption process, ${ }^{[14]}$ and consequent entrapment within the reed bed system. Another issue of the sludge based reed bed is the potential risk of clogging during long-term operation. The trial system efficiently removed influent SS (see Fig. 3 and Table 2) without apparent clogging, but long-term trial periods will be required.

[Fig. 4 here]

\section{DISCUSSION}

The target of this study is to explore the potential reuse of dewatered alum sludge as substrate in reed bed treatment systems. It can be observed from the results that alum 
sludge appears to be an attractive alternative to gravel for use in reed bed systems. A possible concern is the long-term hydraulic conductivity of the dewatered alum sludge. The sludge is expected provide greater conductivity than soil for the wastewater to flow through because normal dewatered alum sludge has reasonable porosity and is voluminous, ${ }^{[16]}$ however soil based systems are specifically designed as free water, surface flow systems and are not typically expected to permit large through-flow of liquid within the soil layer. A recent study on water treatment residuals has shown that the organic carbon content increased their microporosity. ${ }^{[17]}$ It is therefore reasonable to expect that the use of the dewatered sludge will provide a similar effect to adding sand to the top of a vertical flow wetland. This common practice increases resistance to the flow and enhances the distribution of wastewater throughout the wetland substrate. The vegetation of Phragmites in reed beds transfers a certain amount of oxygen into their rhizosphere. Also, the development of the roots via reeds growth will open up extra passageways for the wastewater. ${ }^{[18]}$

Compared with the data derived from the operation of the two beds system (see Table 1 and 2), it appears that the horizontal flow reed bed exhibited a better performance over the vertical flow un-vegetated bed regarding the pollutants removal. Although the identical alum sludge was filled inside the two beds and it is believed that the bed substrate plays a key role in the multi-functions of physicochemical and biological removal processes, the difference in removal efficiencies of the two beds studied is attributed to the different operation time and the significant gap in pollutant loadings. 
Actually the vertical flow un-vegetated bed is somehow a sludge based filter. Due to the relative short time of operation, there is lack in biological activity and the performance is mainly physicochemical process, especially the immobilization of $\mathrm{P}$ (under high loading of $47 \mathrm{~g} \mathrm{PO}_{4}{ }^{3-} / \mathrm{m}^{2}$.d with $99.5 \%$ removal). Relatively, the COD removal is reasonably low. In contrast, operation of the horizontal flow reed bed is for 193 days, which allows the development of biological activities inside the bed. COD and $\mathrm{BOD}_{5}$ removals were thus high even in the higher loadings after 140 days operation (Table 2). Under such a long period of operation, alum sludge continuously exhibited an excellent P removal. Therefore, it is reasonable to expect that the vertical flow bed will show a good removal of pollutants in a long time operation and the two beds studied currently are not comparative in their performance.

It should be pointed out that questions such as the longevity of alum sludge based reed bed treatment systems with regard to P-saturation, clogging tendency, possible release of $\mathrm{Al}^{3+}$ and other toxic substances from the sludge etc. are still remaining. It is noted that full-scale application of the alum sludge based reed bed cannot be initiated until the above questions are fully addressed. Nevertheless, this study has made an attempt to integrate the "free and locally available waste material" into reed bed treatment systems to serve the dual functions of appropriate re-use of the "waste" material and enhanced reed bed treatment efficiencies. Obviously, these potential benefits are worth further investigation. 


\section{CONCLUSIONS}

The dewatered alum sludge has been demonstrated to be a value-added material as a potential low-cost substrate media in reed beds for wastewater treatment. This waste byproduct of the drinking water treatment process has demonstrated its treatment ability in two simulated laboratory scale reed beds, using farmyard wastewater as the influent. Results show that the model vertical flow un-planted bed exhibited a $99.5 \%$ immobilization of influent $\mathrm{P}$. COD reduction of $25 \%$ was achieved under the lack of biological activity in a short time operation of the bed. The horizontal flow alum sludge based reed bed removed $78 \% \mathrm{BOD}_{5}, 82 \% \mathrm{COD}$ and $93 \% \mathrm{SS}$ under a hydraulic loading of $0.80 \mathrm{~m}^{3} / \mathrm{m}^{2}$.d. In particular, the reed bed exhibited an excellent $\mathrm{P}$ removal ability with 92\% P-removal achieved at a loading of $21.5 \mathrm{~g}-\mathrm{PO}_{4}{ }^{3-} / \mathrm{m}^{2} . \mathrm{d}$ regarding a long time operation of 193 days. Although no serious operational problem, such as clogging and $\mathrm{Al}^{3+}$ release was observed, further research is necessary on a larger scale.

\section{ACKNOWLEDGEMENTS}

The authors thank the financial support received from the Irish Environmental Protection Agency under the Environmental Technologies Scheme (project No. 2005ET-MS-38-M3). Mr. P. Kearney and F. Dillion are thanked for their invaluable technical assistance during this study. 


\section{REFERENCES}

[1] Babatunde, A.Q.; Zhao, Y.Q. Constructive approaches towards water treatment works sludge management: An international review of beneficial re-uses. Crit. Rev. Environ. Sci. Technol. 2007, 37(2), 129-164.

[2] Kadlec, R.H.; Knight, R.L. (1996) Treatment wetlands. 1996, Lewis Publishers, New York, USA.

[3] Zhu, T.; Jenssen, P.D.; Maehlum, T.; Krogstad, T. Phosphorus sorption and chemical characteristics of lightweight aggregates (LWA)—Potential filter media in treatment wetlands. Wat. Sci. Tech., 1997, 35(5) 103-108.

[4] Drizo, A.; Frost, C.A.; Smith, C.A.; Grace, J. Phosphate and ammonium removal by constructed wetlands with horizontal subsurface flow, using shale as a substrate. Wat. Sci. Tech., 1997, 35(5) 95-102.

[5] Molle, P.; Lienard, A.; Grasmick, A.; Iwema, A.; Kabbabi, A. Apatite as an interesting seed to remove phosphorus from wastewater in constructed wetlands. Wat. Sci. Tech., 2005, 51(9) 193-203.

[6] Prochaska, C.A.; Zouboulis, A.I. Removal of phosphates by pilot vertical-flow constructed wetlands using a mixture of sand and dolomite as substrate. Ecological Engineering. 2006, 26(3), 293-303.

[7] Heal, K.V.; Dobbie, K.E.; McHaffie, H.; Simpson, A.E.; Smith, K.A. Enhancing phosphorus removal in constructed wetlands with ochre from mine drainage treatment. Wat. Sci. Tech., 2005, 51(9) 275-282. 
[8] Dong, C.S.; Ju, S.C.; Hong, J.L.; Jong, S.H. Phosphorus retention capacity of filter media for estimating the longetivity of constructed wetland. Wat. Res. 2005, 39(11), 2445-2457.

[9] Leader, J.W.; Reddy, K.R.; Wilkie, A.C. Optimisation of low-cost phosphorus removal from wastewater using co-treatments with constructed wetlands. Wat. Sci. Tech., 2005, 51(9) 283-290.

[10] Basibuyuk, M.; Kalat, D.G. The use of waterworks sludge for the treatment of vegetable oil refinery industry wastewater. J. of Environmental Technology, 2004, 25(3), 373-380.

[11] Yang, Y.; Tomlinson, D.; Kennedy, S.; Zhao, Y.Q. Dewatered alum sludge: A potential adsorbent for phosphorus removal. Wat. Sci. Tech. 2006, 54(5), 207-213.

[12] Zhao, Y.Q.; Babatunde, A.O. Reuse of water treatment sludge as an adsorbent for phosphorus immobilization. In: Proceedings of IWA Specialized ConferenceSustainable Sludge Management: State of the art, challenges and perspectives. pp. 626-633. Moscow, Russia, 2006.

[13] Razali, M.; Zhao, Y.Q.; Bruen, M. Effectiveness of a drinking-water treatment sludge in removing different phosphorus species from aqueous solution, Separation and Purification Technology, 2007, 55(3), 300-306.

[14] Yang, Y.; Zhao, Y.Q.; Babatunde, A.O.; Wang, L.; Ren, Y. X; Han, Y. Characteristics and mechanisms of phosphate adsorption on dewatered alum sludge. Separation and Purification Technol, 2006, 51(2), 193-200. 
[15] Arias, C.A.; Brix, H. Phosphorus removal in constructed wetlands: can suitable alternative media be identified? Wat. Sci. Tech., 2005, 51(9) 267-273.

[16] Dalton, T. Innovations in Potable Water Sludge Treatment and Disposal. CIWEM publications, 2002. London, UK.

[17] Markis, K.C.; Harris, W.G. Time dependency and irreversibility of water treatment desorption by drinking-water treatment residual: Implications for sorption mechanisms. Colloids and Interface Science, 2006, 294(1), 151-154.

[18] Brix, H. Do macrophytes play a role in constructed treatment wetlands? Wat. Sci. Tech., 1997, 35(5) 11-17. 
Table list

Table 1 Summary of the vertical flow un-vegetated wetland operation

\begin{tabular}{ccccc}
\hline & \multicolumn{4}{c}{ Overall operation (in mean values) } \\
\cline { 2 - 5 } Parameter & Loading $\left(\mathrm{g} / \mathrm{m}^{2} . \mathrm{d}\right)$ & Inf. $(\mathrm{mg} / \mathrm{L})$ & Efflu. $(\mathrm{mg} / \mathrm{L})$ & Removal $(\%)$ \\
\hline $\mathrm{COD}$ & 371.4 & 159.7 & 119.3 & 25.3 \\
$\mathrm{PO}_{4}{ }^{3-}$ & 47.1 & 20.3 & 0.1 & 99.5 \\
$\mathrm{SS}$ & 181.1 & 77.9 & 39.1 & 49.8 \\
$\mathrm{pH}$ & - & 7.3 & 7.1 & - \\
\hline
\end{tabular}

Table 2 Summary (mean values) of the horizontal flow vegetated wetland operation

\begin{tabular}{ccccccccccc}
\hline & \multicolumn{3}{c}{ Operation within 140 days } & & \multicolumn{3}{c}{ Operation beyond 140 days } \\
\cline { 2 - 4 } Parameter & $\begin{array}{c}\text { Loading } \\
\left(\mathrm{g} / \mathrm{m}^{2} . \mathrm{d}\right)\end{array}$ & $\begin{array}{c}\text { Inf. } \\
(\mathrm{mg} / \mathrm{L})\end{array}$ & $\begin{array}{c}\text { Efflu. } \\
(\mathrm{mg} / \mathrm{L})\end{array}$ & $\begin{array}{c}\text { Removal } \\
(\%)\end{array}$ & & $\begin{array}{c}\text { Loading } \\
\left(\mathrm{g} / \mathrm{m}^{2} . \mathrm{d}\right)\end{array}$ & $\begin{array}{c}\text { Inf. } \\
(\mathrm{mg} / \mathrm{L})\end{array}$ & $\begin{array}{c}\text { Efflu. } \\
(\mathrm{mg} / \mathrm{L})\end{array}$ & $\begin{array}{c}\text { Removal } \\
(\%)\end{array}$ \\
\hline $\mathrm{BOD}_{5}$ & 77.2 & 96.5 & 30.4 & 68.5 & & 181.3 & 226.6 & 50.5 & 77.7 \\
$\mathrm{COD}$ & 132.1 & 165.1 & 54.3 & 67.1 & & 297.4 & 371.7 & 66.4 & 82.1 \\
$\mathrm{PO}_{4}{ }^{3-}$ & 10.9 & 13.7 & 1.3 & 90.5 & & 21.5 & 26.8 & 2.2 & 91.8 \\
$\mathrm{SS}$ & 46.6 & 58.2 & 6.1 & 89.5 & & 110.6 & 138.2 & 9.9 & 92.8 \\
\hline
\end{tabular}




\section{Figure caption}

Figure 1 Schematic diagram of (A) vertical flow un-vegetated sludge bed, and (B) horizontal flow vegetated sludge bed

Figure 2 Experimental results of vertical flow un-vegetated sludge wetland

Figure 3 Experimental results of horizontal flow vegetated sludge wetland

Figure 4 Effluent $\mathrm{Al}^{3+}$ during the entire trial 


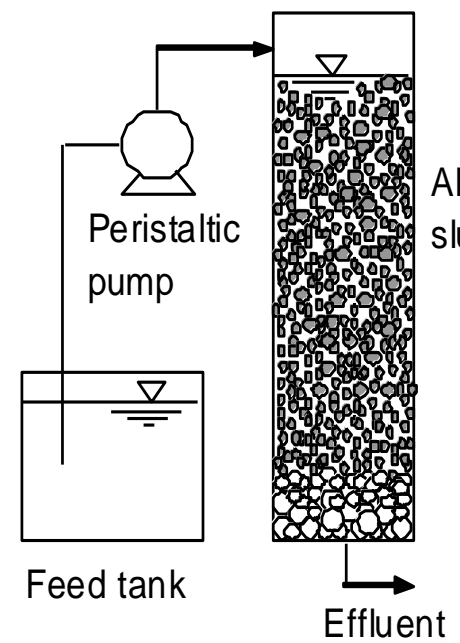

(A)
Alum

sludge
Reeds

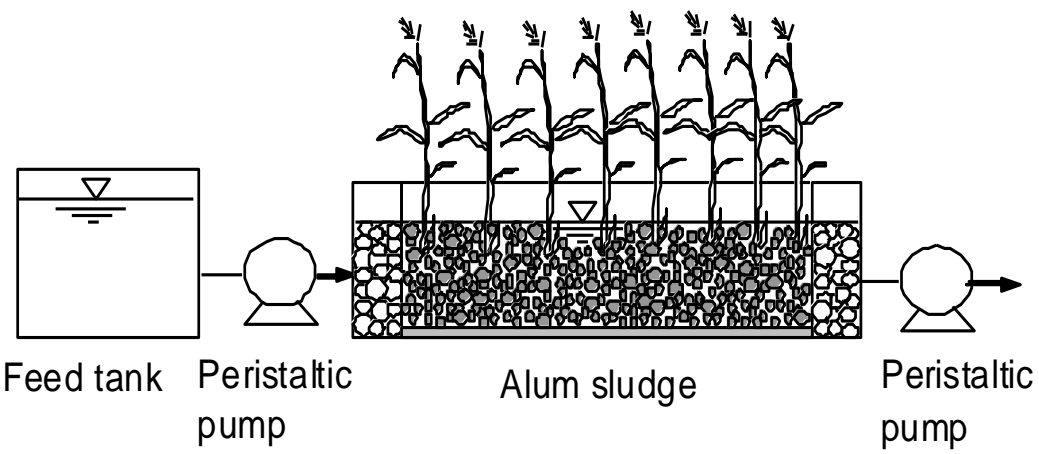

(B)

Fig. 1 


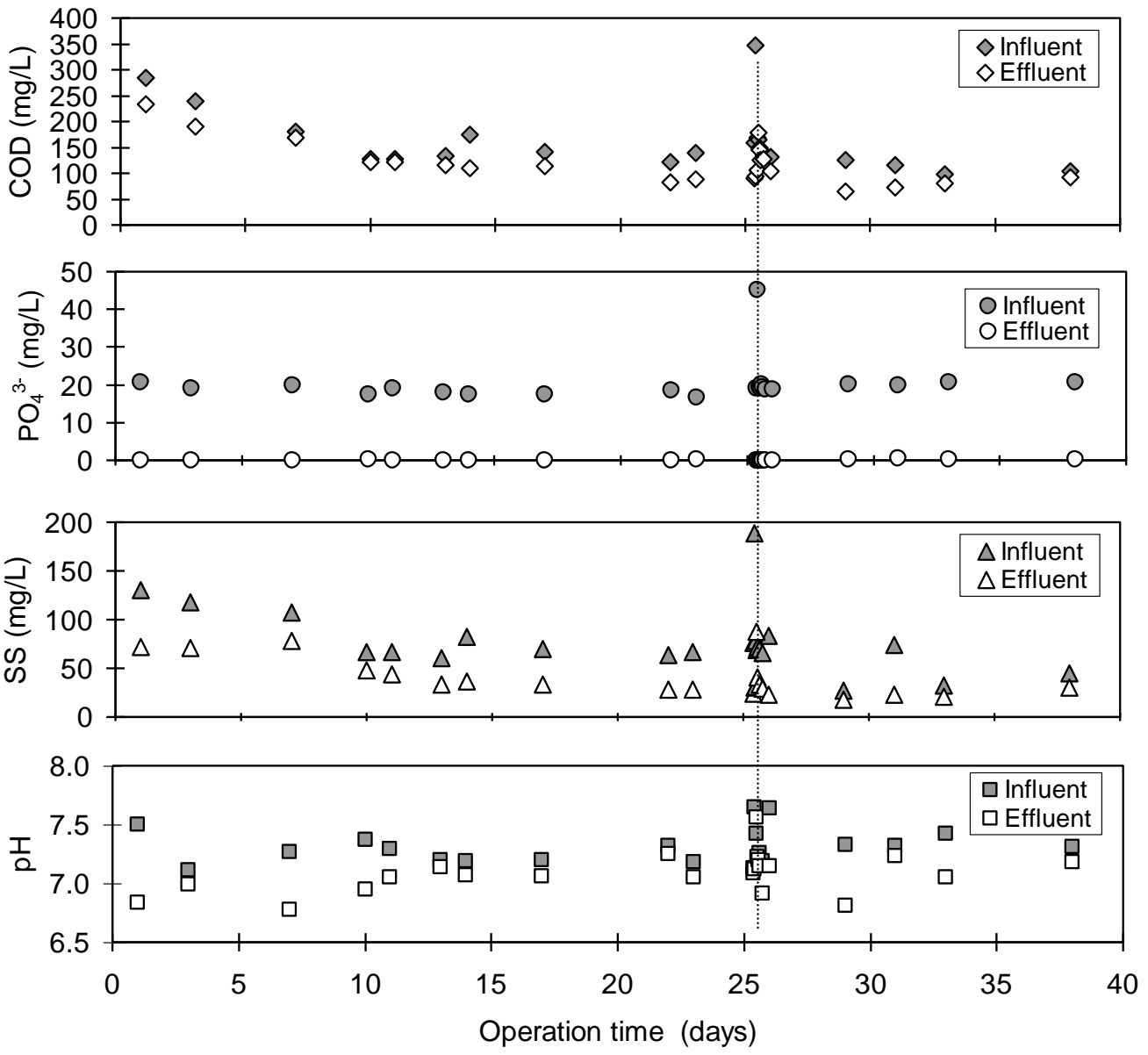

Fig. 2 

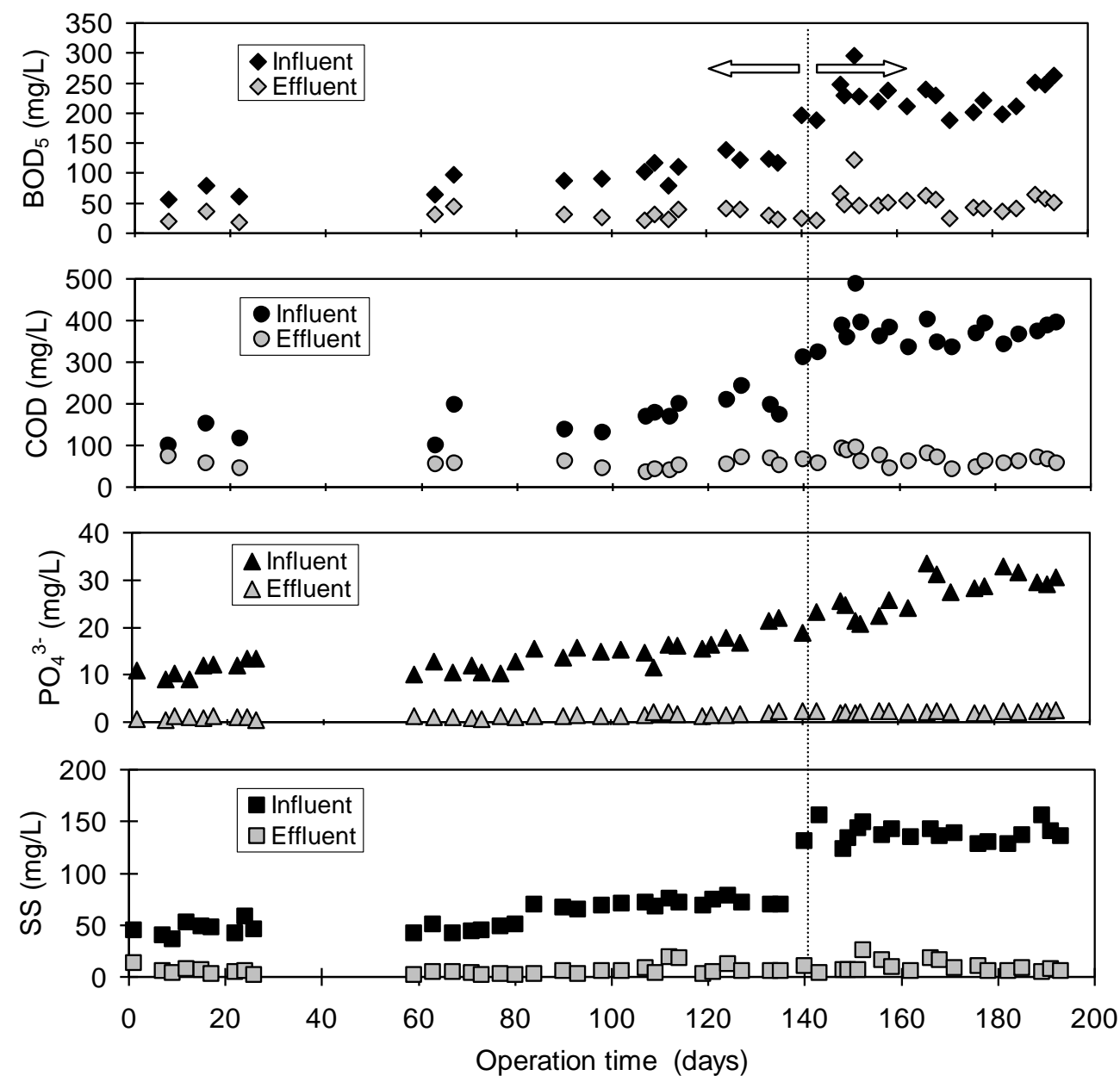

Fig. 3 


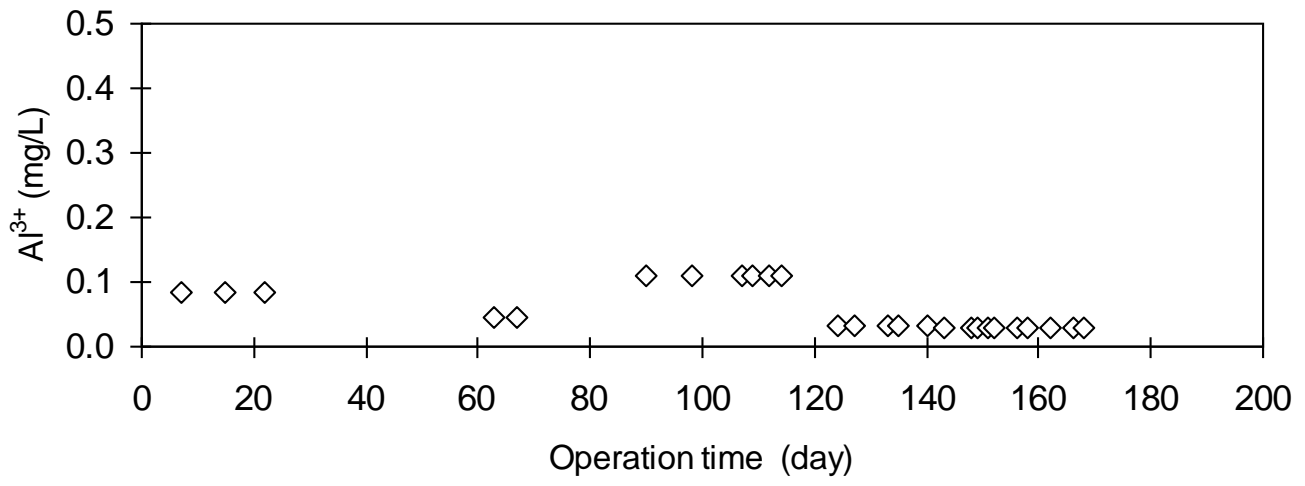

Fig. 4 